\title{
The Recent History of Subalpine Krummholz Pines (Pinus sylvestris) in the Swedish Scandes
}

\author{
Leif Kullman $^{1 *}$, Lisa Öberg ${ }^{2}$ \\ ${ }^{I}$ Department of Ecology and Environmental Science, Umeå University, 90187 Umeå. Sweden \\ ${ }^{2}$ OldTjikko Photo Art \& Science, Handöl 544, 83771 Duved, Sweden
}

*Corresponding Author: Leif Kullman, Department of Ecology and Environmental Science, Umeå University, 90187 Umeå. Sweden

\begin{abstract}
This paper accounts for photographic surveys of stunted old-growth krummholz pines (Pinus sylvestris) in the context of climate change and variability since the late 1970s and early 1980s. The study was conducted within the alpine-tundra ecotone of the southern Swedish Scandes. The life-histories of pines with this shrubby and stunted growth mode are little studied. They may play some role as dispersal nuclei, contributing to elevational treeline rise in cases of future climate warming. In contrast to earlier assumptions, it now appears that pines, growing in open spaces of the subalpine birch forest belt, may regenerate vegetatively by layering, enabling surprisingly old ages. Having survived the harsh centuries of the Little Age, they have recently attained tree stature and started to produce offspring in their near vicinity. Thereby they contribute to ongoing pine treeline rise and transformation of the forest-alpine tundra ecotone.
\end{abstract}

Keywords: Krummholz, Pinus sylvestris, treeline ecotone, climate change, regeneration. layering.

\section{INTRODUCTION}

Currently, concern about future climate change and its consequences for society and biota is commonplace. In this context, alpine (upper) treelines ${ }^{1}$ and their spatial and compositional dynamiscs stand out as important proxy indicators of past and recent climate and environmental change (Behringer 2010). They are basically renowned to reflect heat deficiency, and are in principle assumed to display straightforward ecological responses to climate dynamics on different spatial and temporal scales (Aas 1969; Kullman 1979, 1998, 2013, 2014a,b; Smithson et al. 2002, Holtmeier 2009; Holtmeier \& Broll 2017a). At the local spatial scale, the detailed mechanisms concerning treeline change and stability are insufficiently known, depending on idiosyncratic combinations of species-specific traits and topoclimate characteristics, often related to wind, snow cover, water availability and human impact (Kullman 1979; Elliott \& Kipfmueller 2010; Leonelli et al. 2011; Holtmeier \& Broll 2012; Alatalo \& Ferrarini 2017). These circumstances hamper realistic projective modeling and may lead to unrealistic results (e.g. Moen et al. 2004; Kaplan \& New 2006; Bernes 2007).

Reproductional traits are fundamental aspects of treeline responses to altered climatic conditions. Important treeline species in the Scandes are mountain birch (Betula pubescens ssp. czerepanovii), Norway spruce (Picea abies) and Scots pine (Pinus sylvestris), with this top-down order of elevational sequence. The two first-mentioned species are since long known to have the potential of vegetative regeneration, producing a bank of long-lived clonal multi-stemmed (krummholz) specimens at and above the current treeline. Notably, most of the treeline rise during the past 100 years was achieved in this way, i.e. by phenotypic plasticity (Kullman 1986; Kullman \& Öberg 2009). In some cases, these specimens are well-established, millennial-old residuals, originating from relatively warm periods during the early Holocene (Öberg \& Kullman 2011, 2012; Kullman 2013), which have survived the harsh Little Ice Age, i.e. 14th to 19th centuries (e.g. Lamb 1982; Grove 2004; Ljungqvist 2017).

In cases of climate warming, these species may short-cut the most critical life-history stages, i.e. seed production, maturation, germination, spread and early growth. As they are already on

${ }^{I}$ Treeline is here narrowly defined as the upper ( $\mathrm{m}$ a.s.l.) individual of a certain tree species with a minimum height of $2 \mathrm{~m}$. 
place, they are able to respond quite readily to altered climatic conditions by increased vertical growth (Kullman 1986, 2015a), faster than seed-generated individuals of other species (cf. Hagedorn et al. 2014). This is a fundamental difference to Pinus, which according to prevailing opinions, is only exceptionally conceived to possess the same ability (Vesterlund 1900; Kilander 1955; Kallio et al. 1971, Holtmeier 2009). Old-age clonally layering Pinus specimens of the same longevity as displayed by Picea and Betula are not reported in the literature, although individual ages around 1000 years have been recorded, as depicted in Figure 4 (Kullman 2011).

In the Swedish Scandes, pine treeline rise during the past century amounts to maximum $225 \mathrm{~m}$ in elevation (Fig. 1), which may be tentatively inferred as the highest position in the past 7000 years or so. This advance was accomplished predominantly by upslope spread and growth of seed-regenerated individuals (Kullman 2017). However, a minor proportion of the sparsely spaced pines within the "advance zone" are old-established krummholz specimens, which existed prior to the onset of the 20th century climatic amelioration (Fig. 2). These pines predominantly grow in open and wind-exposed spaces, mainly within the lower birch forest belt, at sites where competition for light and nutrients are minimal (Franke et al. 2019; Kullman \& Öberg 2018). At these elevations, the light-demanding pine is, in general, excluded primarily by competition from the fairly dense birch stands, prevailing hereabouts. Given a warmer and drier future climate, the subalpine birch forest may disintegrate, which opens a broad window for pine advance (Kullman 2020). Preexisting krummholz pines, transforming into upright trees, may then come to play a progressive role as seed producers and modulators of the local climate. Thereby they may facilitate the formation of a novel treeline ecotone (cf. Bekker 2005; Holtmeier \& Broll 2017a, b, c), i.e. subalpine belt predominantly composed of pine (Kullman 2020). Thus, the life and growth dynamics of old-age krummholz pines needs to be studied in more detail. That is the main rationale with this paper, which accounts for the continuous surveillance during the past 40 years of three old-established krummholz specimens in the southern Swedish Scandes.

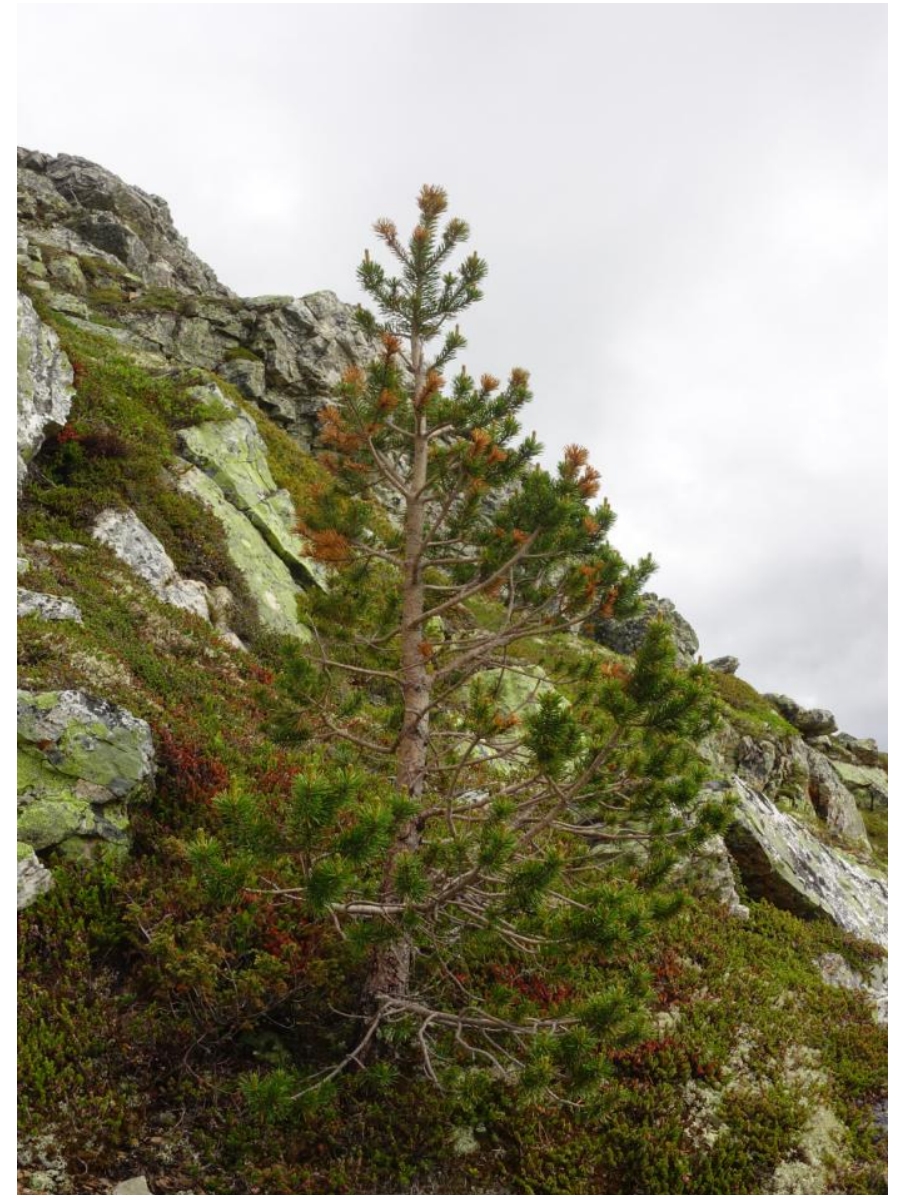

Fig. 1. The predominant mode of current pine treeline advance is upslope spread of seed-generated individuals. This specimen represents advance by 225 altitudinal meters since the early 20th century. Mt. Molnet (Dalarna province), $1100 \mathrm{~m}$ ö.h. Photo: 2017-07-03. 


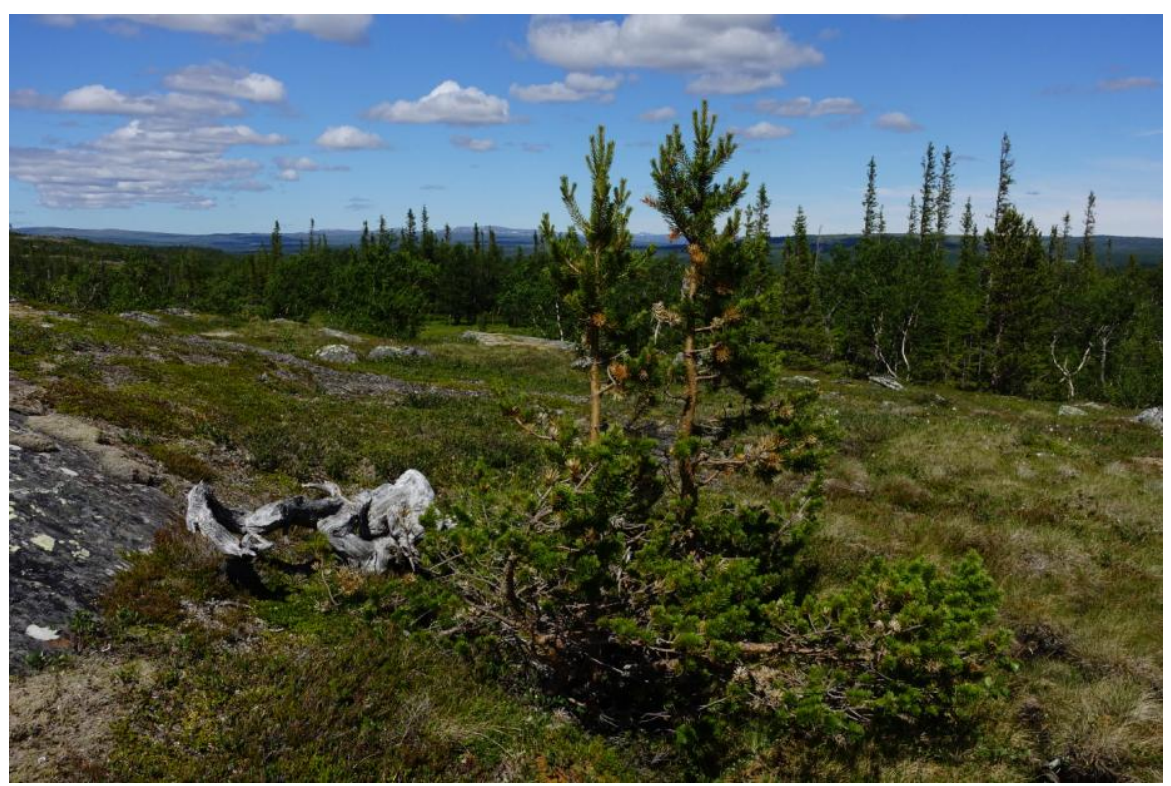

Fig. 2. Old-age krummholz pine in wind-exposed terrain, somewhat below the local treeline. It transformed into tree size by release of vertical stems from wind-stressed modes, concurrent with climate warming in recent time. Observations of this kind highlight the possible role of analogous pine responses to ongoing treeline adjustmenst to climate warming, i.e. the main focus of this study.Mt. Storsnasen 635 m a.s.l. Photo: 2016-07-29.

\section{FOCAL SITES AND SPECIMENS}

The study was carried out in the southern Swedish Scandes (Jämtland province), within the Handölan Valley (Fig. 3). This valley trends north to south, with surrounding mountain peaks reaching 1400$1500 \mathrm{~m}$ a.s.l. The mountain floor and lower slopes are covered with mountain birch forest and widely scattered pines and spruces. The treeline elevation of birch varies between 900 and c.1100 m a.s.l., depending on local site conditions.

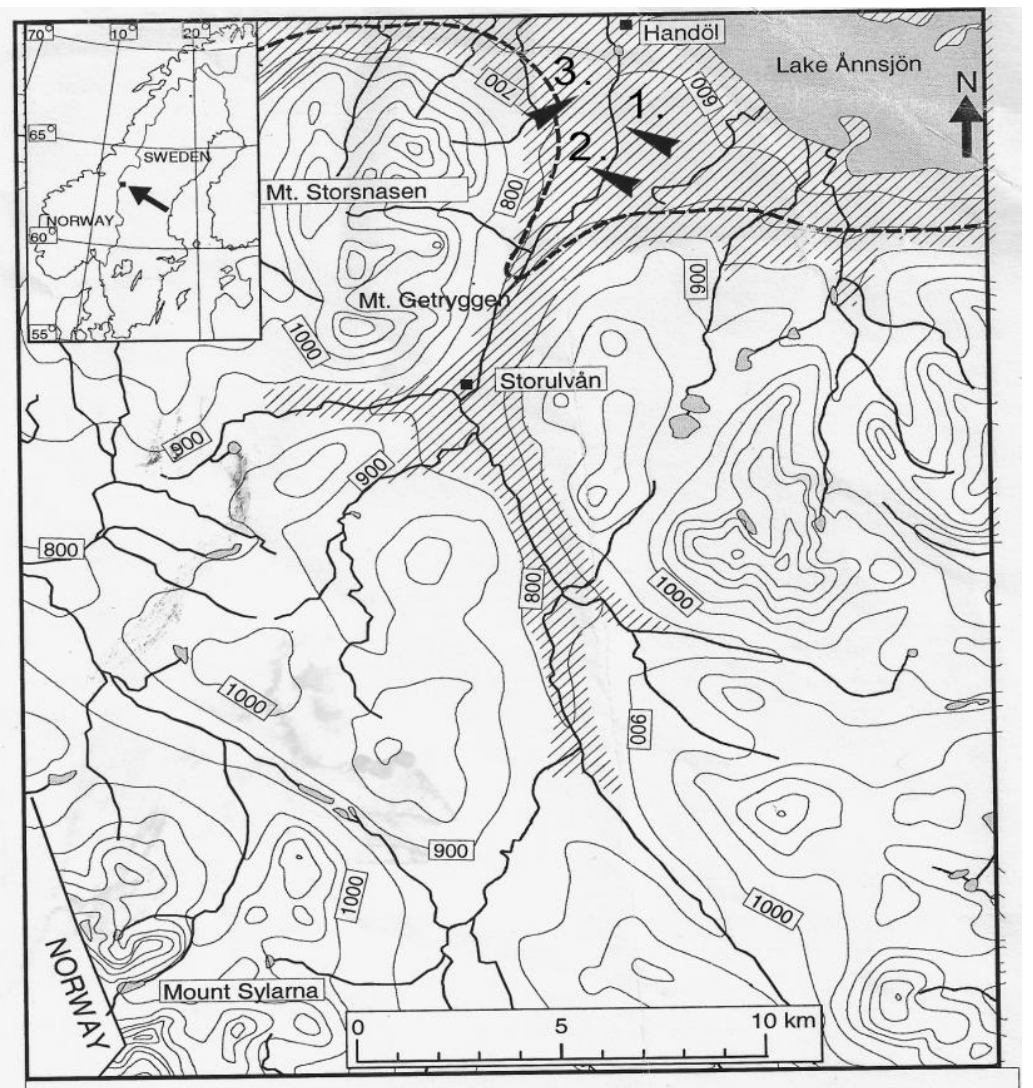

Fig. 3. Location of the study sites (arrows), within the Handölan Valley. The hatched line denotes the limit of more or less coniferous forest. Shaded areas beyond are mountain birch forest with scattered pines and spruces. The lighter areas are treeless alpine tundra. 
Climate evolution (1901-2019) is taken from the meteorological station Storlien/Visjövalen, $642 \mathrm{~m}$ a.s.l. and ca. $20 \mathrm{~km}$ to the northwest of the study objects. Summer (June to August) and winter (December to February) temperature increased by 1.6 and $1.5^{\circ} \mathrm{C}$, respectively (Kullman in 2020).

Three representative krummholz pines (1,2 and 3) have been photographically surveilled (summer and winter) annually since the late 1970s and early 1980s. Particular focus has been on maximum height, winter needle and shoot injuries and emergence of saplings in the nearest surroundings.

1. The west-facing slope of Mt. Täljstensvalen, 745 m ö.h. ( $63^{\circ} 14,548^{\prime} \mathrm{N} ; 12^{\circ} 27,1^{\prime} 1^{\prime}$ E). The site is severely wind-stressed, with frequent open wind-scars in the surrounding heaths with predominant Empetrum hermaphroditum. The location is about $20 \mathrm{~m}$ below the treelines of pine, spruce and birch, which all linger close to the summit of this low mountain (780 $\mathrm{m}$ a.s.1.).

2. Close to the valley floor on the east-facing slope of Mt. Storsnasen, $685 \mathrm{~m}$ a.s.1. $\left(63^{\circ} 13,505^{\prime} \mathrm{N}\right.$; $\left.12^{\circ} 24,945^{\prime} \mathrm{E}\right)$. The local treelines of birch, spruce and pine are 925,865 and $800 \mathrm{~m}$ a.s.l., respectively. The site is a widely open and windswept part of the landscape, with extensive treeless mires and scattered groves of birch forest and solitary pines and spruces on drier ground.

3. Northeast-facing slope of Mt. Storsnasen, $635 \mathrm{~m}$ a.s.1. $\left(63^{\circ} 15,065^{\prime} \mathrm{N}, 12^{\circ} 25,502^{\prime} \mathrm{E}\right)$. The local treelines are the same as given for pine no. 2. This pine grows on an open mire with a sparse snow cover during most winters.

\section{RESULTS}

Under this heading, photos of the three pines, specifically focused in this study, are displayed as the main results of this study. The images are complemented with some comments and metrics, quantifying possible change overthe past 40 years or so.

\section{PINE 1}

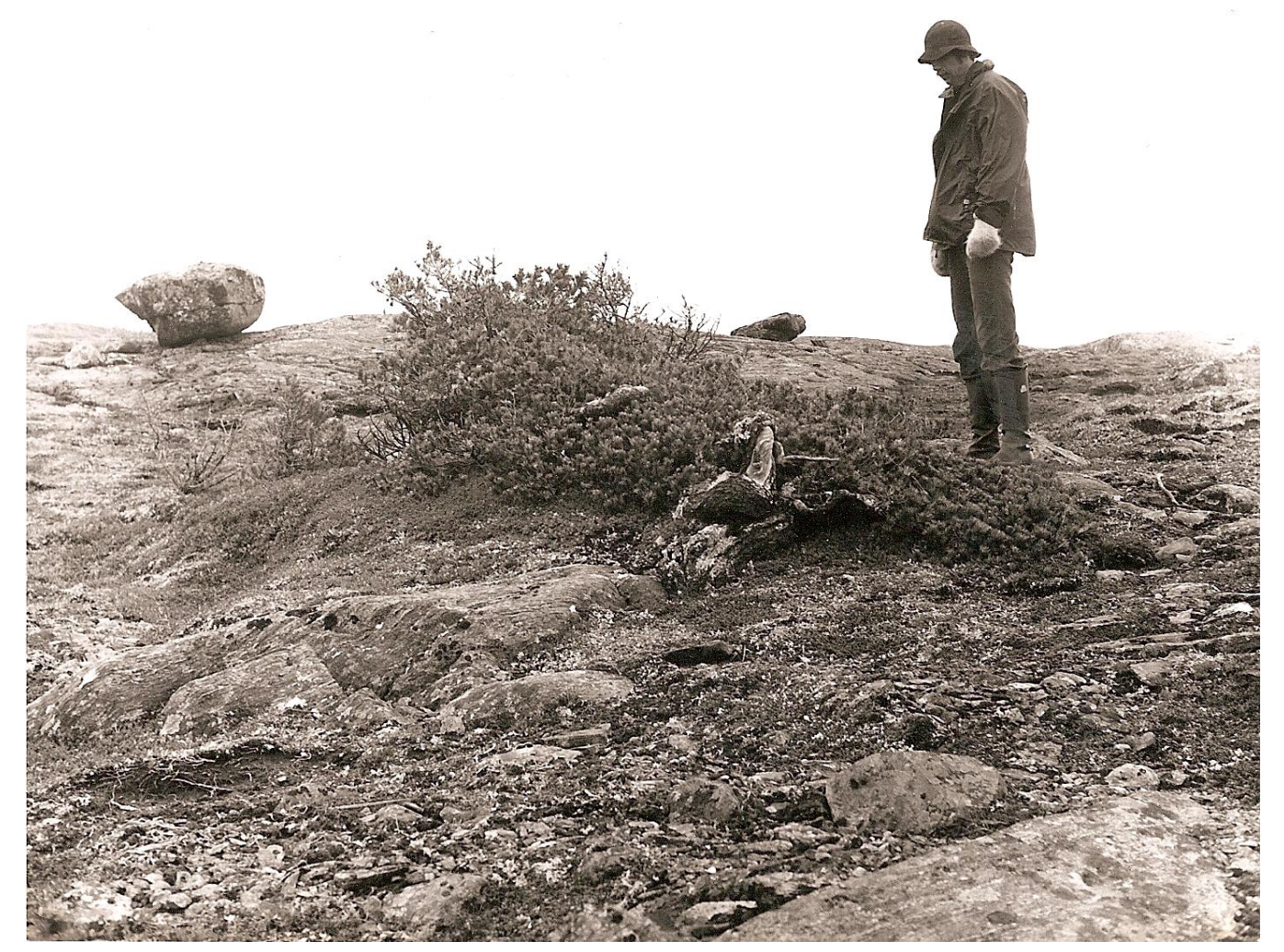

Fig. 4. Wind-exposed, old-age krummholz pine with a wind/snow and ice blast scar on the w-facing part of the fairly stout main stem. The highest leader is $0.6 \mathrm{~m}$. Rotten remains of the main stem were radiocarbon-dated to about 1000 years before the present day (Kullman 2011). Photo: 1981-06-10. 


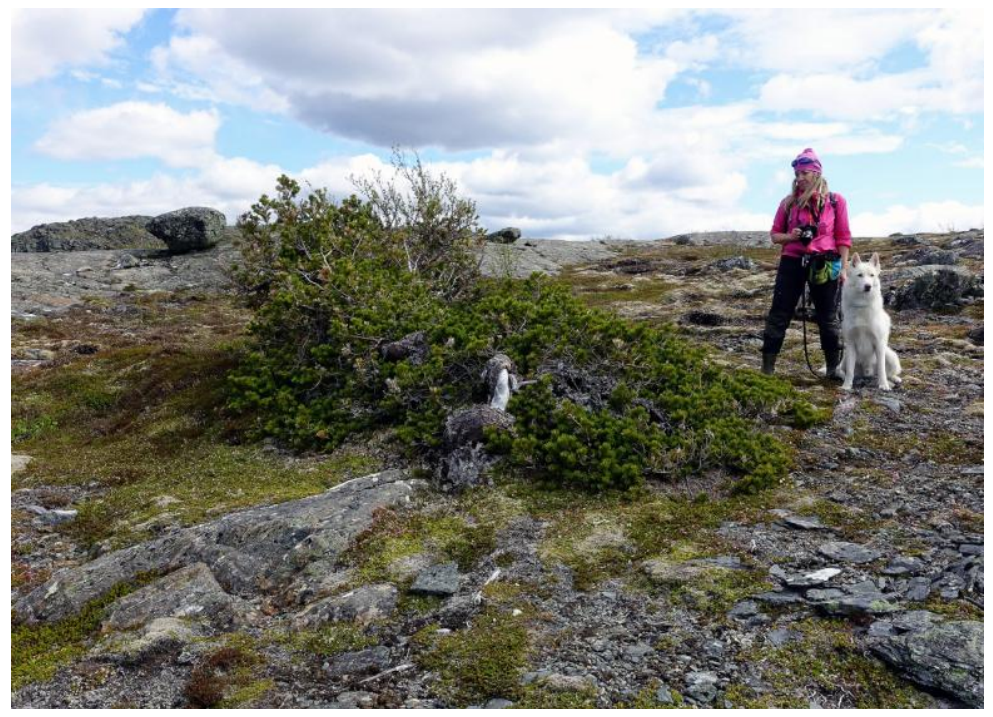

Fig. 5. Since the early 1970s, stature and density of the pine has increased. The maximum height is $2.1 \mathrm{~m}$ in 2019, which means that this a tree, according the adopted definition. Notably, also the sheltered birch in the background has gained in height. Photo: 2017-06-11.

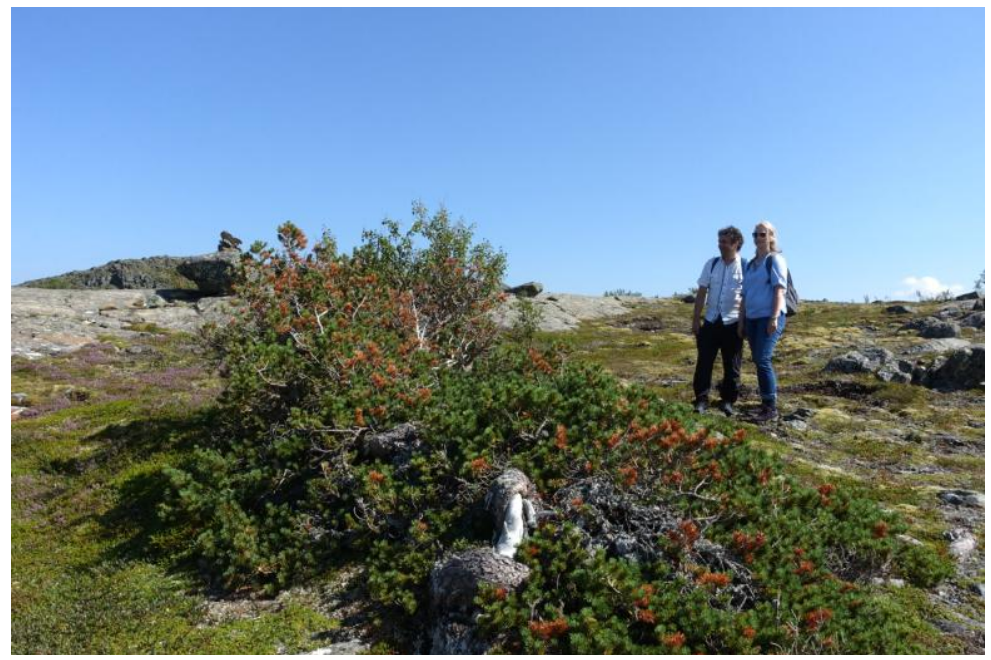

Fig. 6. Between 2017 (Fig. 5) and 2019, the pine has suffered some winter-desiccation injuries to shoots projecting above the snow cover. This is a kind of "bonsai" mechanism which has conserved the shape and longevity of this specific life-form. Photo: 2019-07-23.

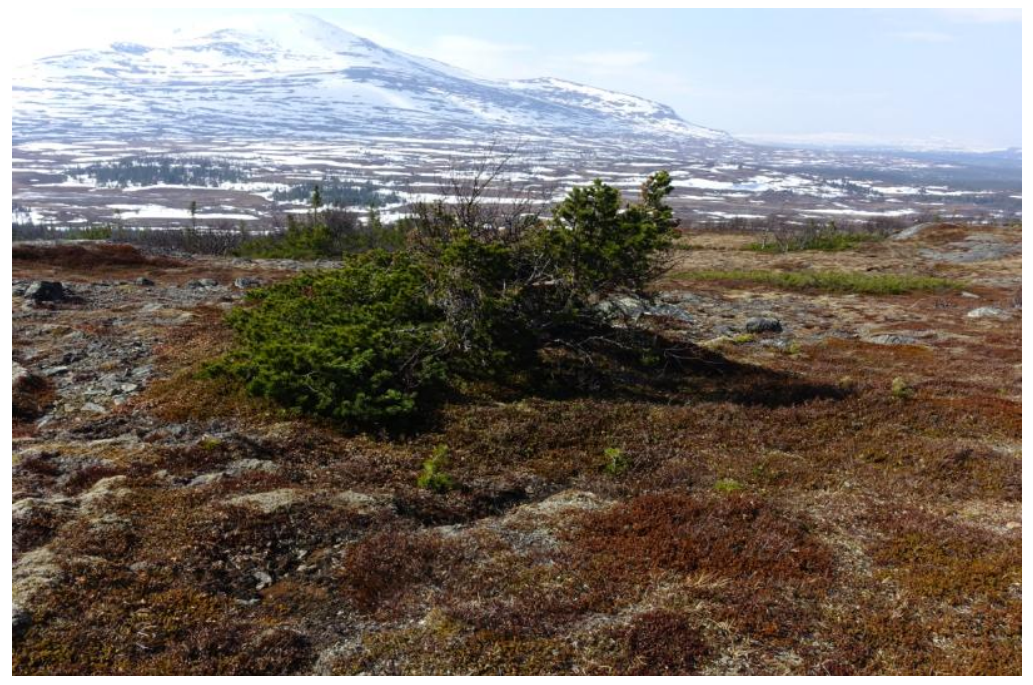

Fig. 7. Height has its maximum, $2.1 \mathrm{~m}$, at the east-facing and least wind-exposed part of the wedge-formed krummholz pine. Here in the vicinity (foreground), saplings have become established during the past decade, which conforms to a general pattern of enhanced pine reproduction in the treeline ecotone (Kullman 2018). Reasonably, these juvenils are the progeny of this pine. Photo: 2019-04-26. 


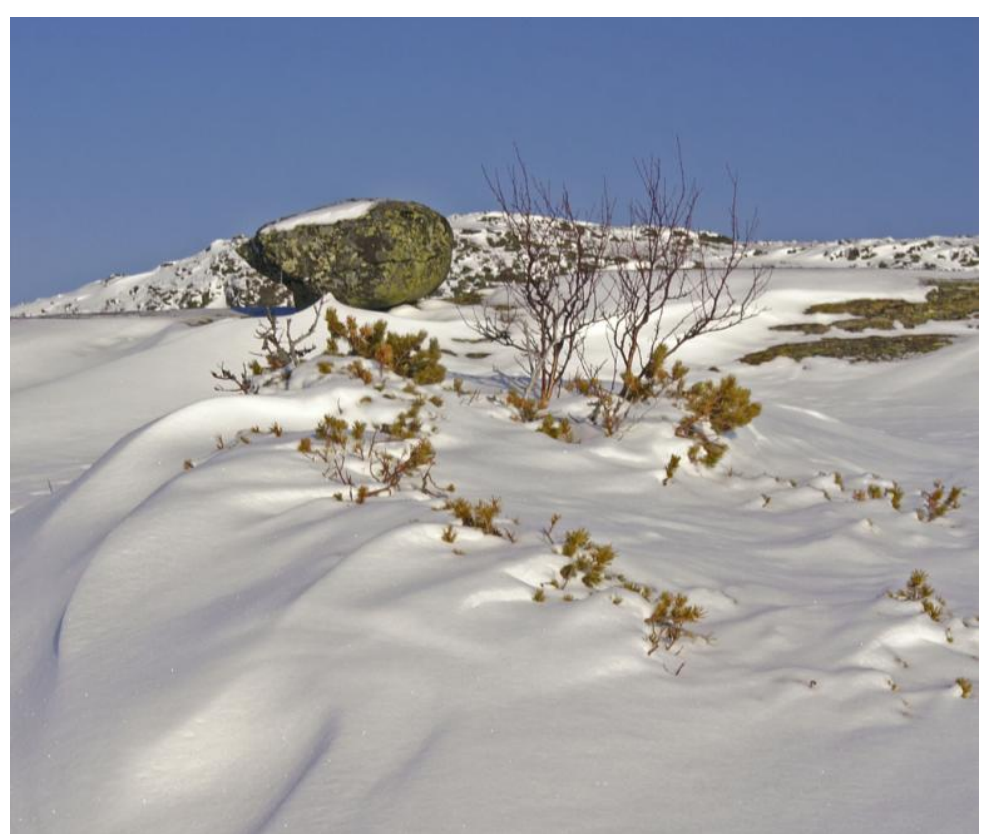

Fig. 8. The pine is largely protected by snow for long periods during the winter. Shoots protruding above the snow surface suffer winter-desication Photo: 2008-03-22.

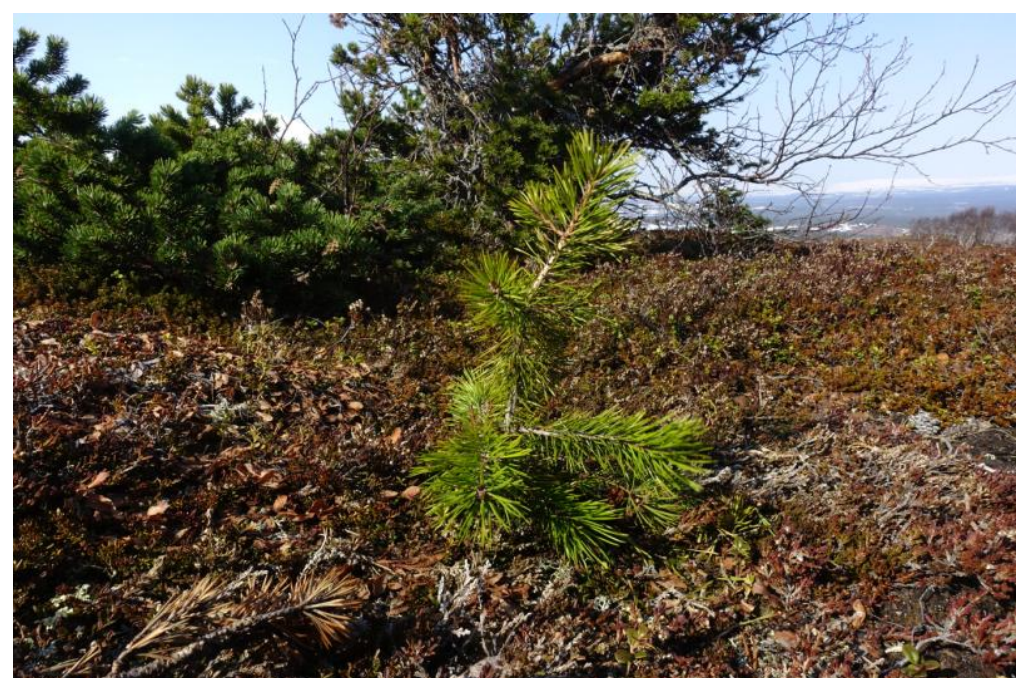

Fig. 9. Pine sapling established in a dense matrix of Calluna vulgaris in shelter of the krummholz pine. Photo: 2019-04-26.

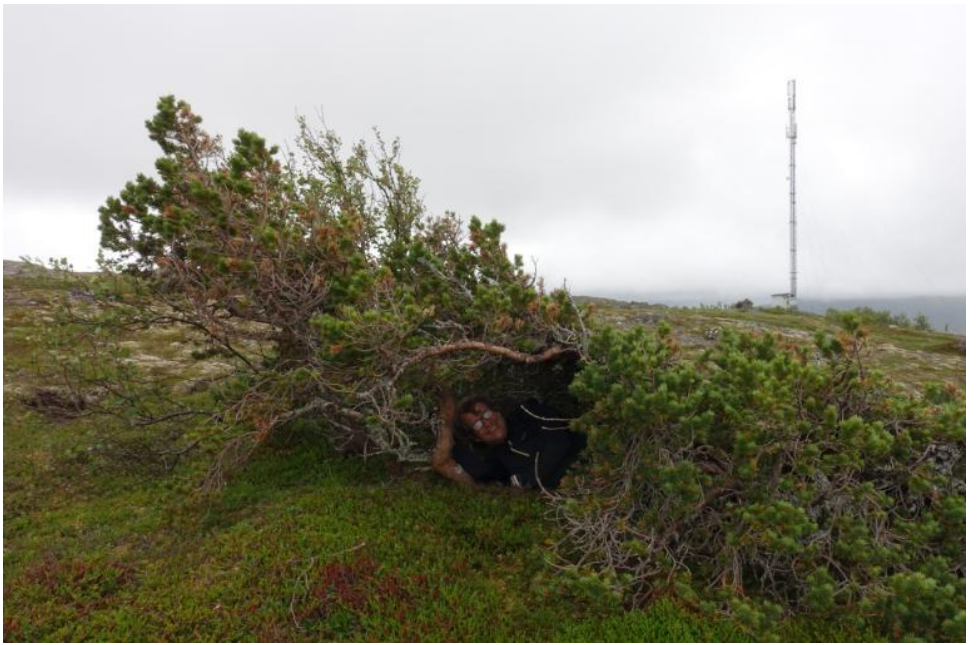

Fig. 10. The pine is composed of an intricate and dense network of interconnected stems, with adventitious roots and more less covered by plant debris.A large and entirely plant-free hollow appears in the center, where a bear could comfortably hibernate. In most respects, it mimics the mode of spruce vegetative regeneration. Photo: 2019-07-23. 
PINE 2

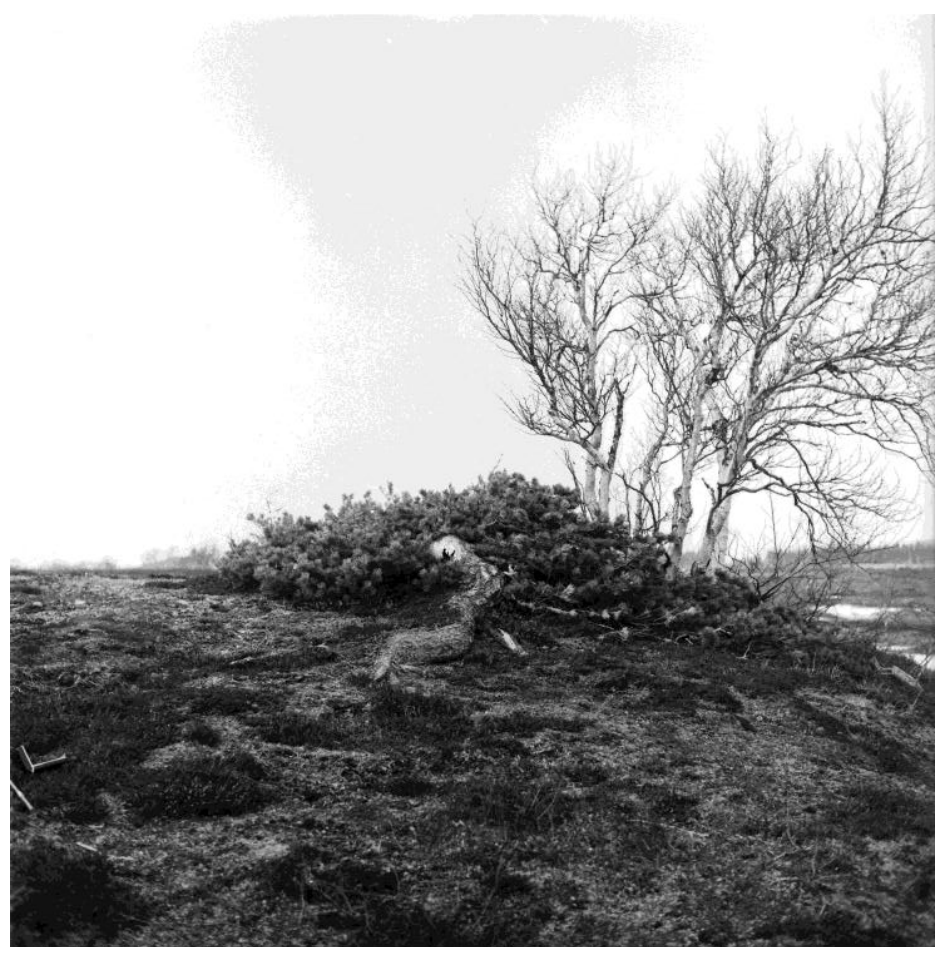

Fig. 11. This pine with its stout and prostrate main stem displays an extension of $3 x 3 \mathrm{~m}$ and a maximum living height of $0.5 \mathrm{~m}$. One dead leader has been slightly more than $1 \mathrm{~m}$ high. Tree-ring counting indicates that the age is at least 350 years. Photo: 1977-05-06.

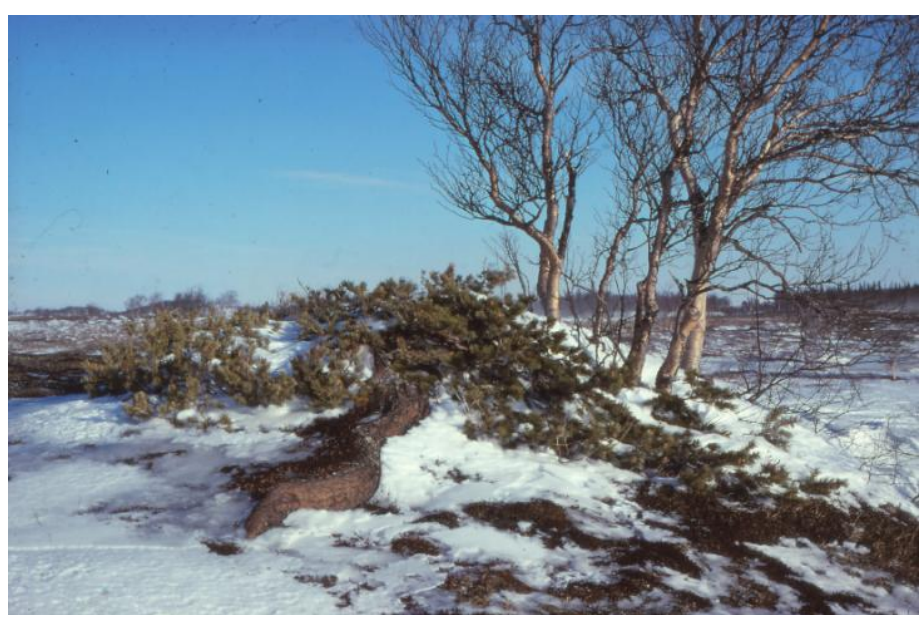

Fig. 12. The winter 1980 was fairly cold and snow poor. Major parts of the canopy was exposed above the snow surface, which was predisposed for winter desiccation of the foliage. Photo: 1980-02-26.

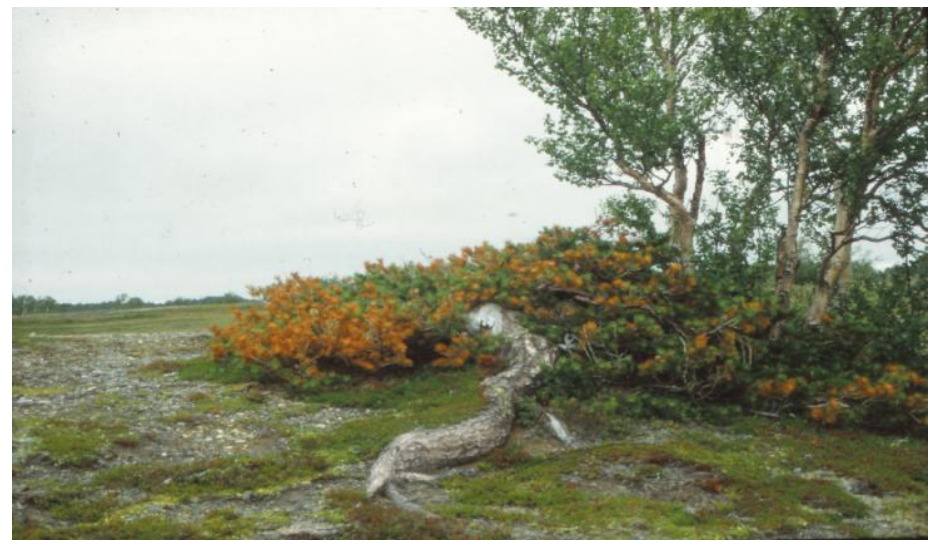

Fig. 13. By the early summer, the injuries from the winter are manifested as browning of the most exposed shoots. Photo: 1980-07-13. 


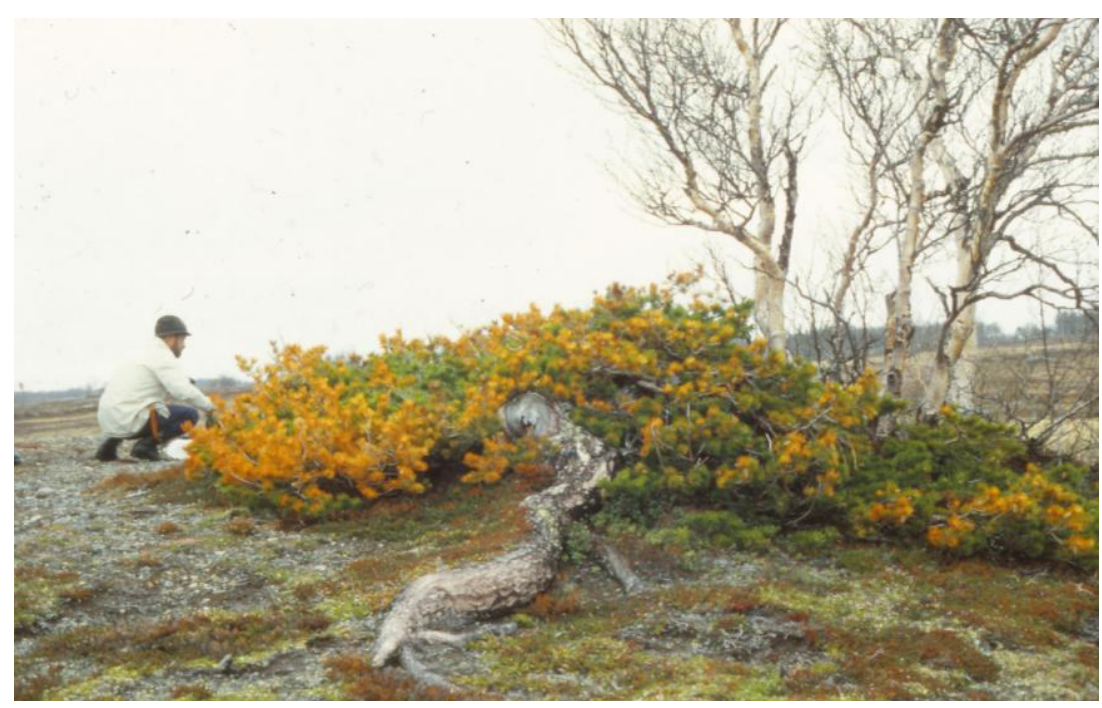

Fig. 14. The injured foliage, highlighted in Fig. 13 still prevailed two years later. Notably, the greenish Empetrum-carpets seen in 1980 (above) have suffered winter-dieback and the Photo: 1982-06-09.

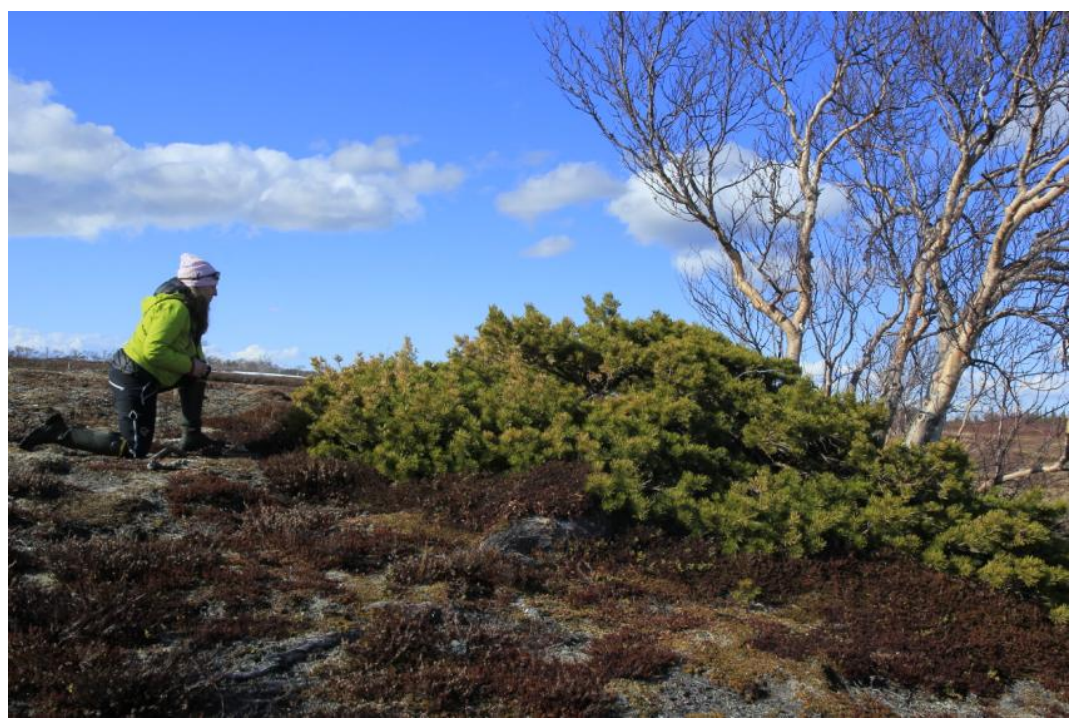

Fig. 15. Following the mid-1990s, winter dieback of the foliage has been insignificant and the appearance of the pine has improved significantly. The maximum height increased to $1.3 \mathrm{~m}$. In addition, the former sparse ground cover of mainly Empetrum hermaphroditun and Kalmia procumbens has massively changed to dense carpets of Calluna vulgaris. Photo: 2013-05-11.

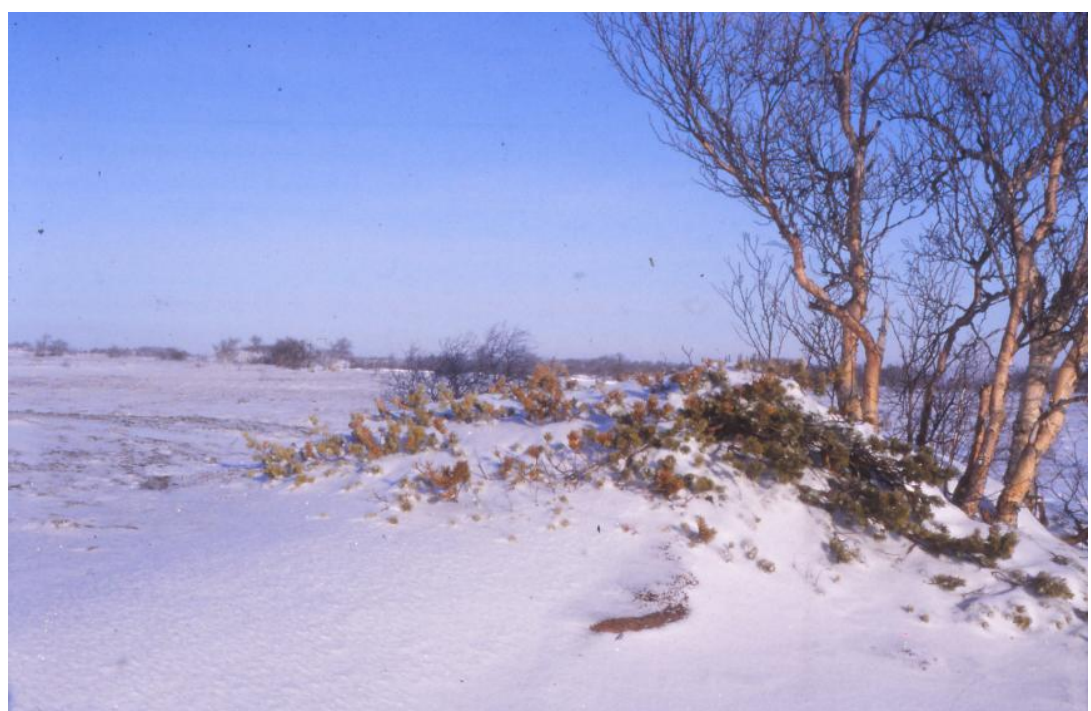

Fig. 16. Another severe winter imposed extensive needle desiccation and set back of canopy expansion. Photo: 1994-02-05. 


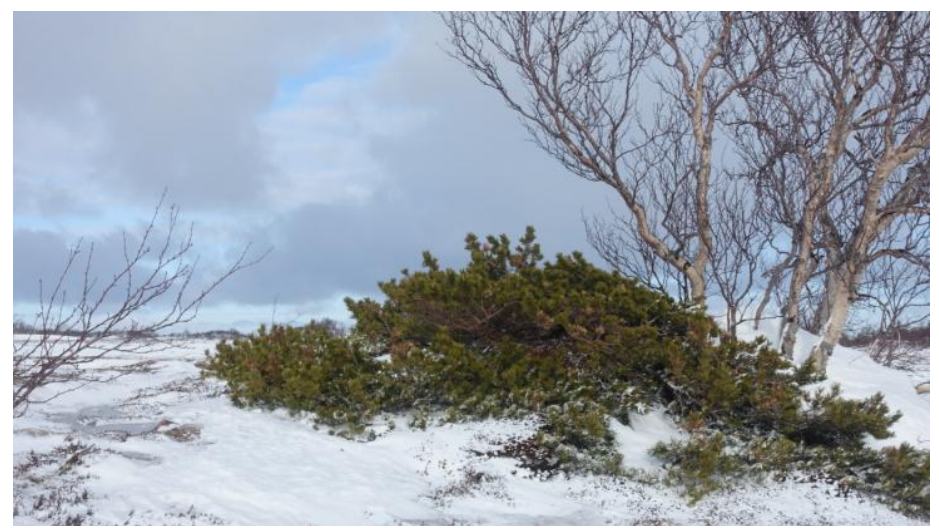

Fig. 17. During the first two decades of the new millennium, winter stress has declined and the maximum height has increased to $1.8 \mathrm{~m}$, soon reaching tree-size. Compared earlier images, the canopy has become fresher and lusher. Photo: 2019-02-20.

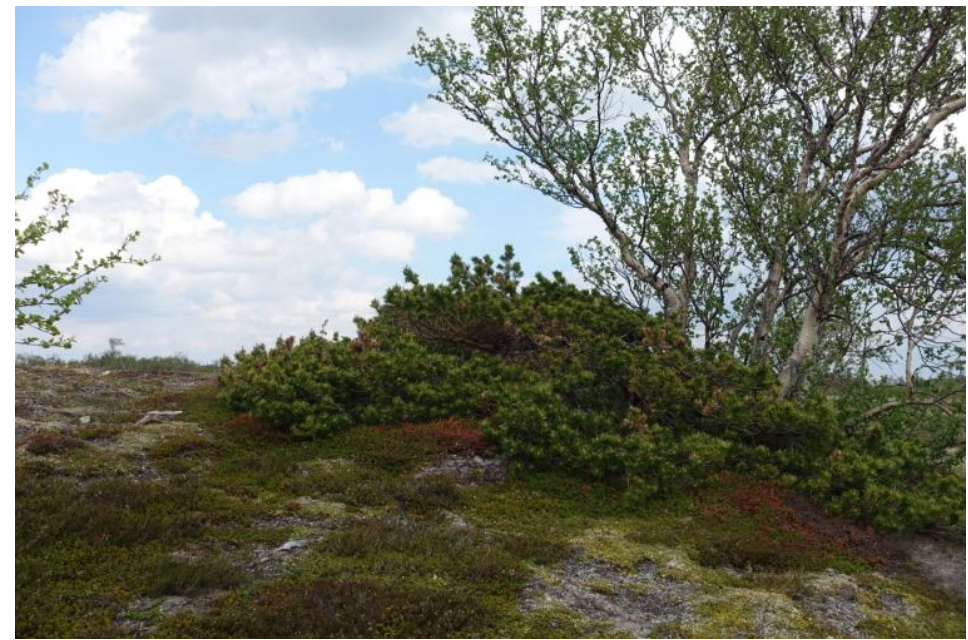

Fig. 18. Summer view of the concerned pine, to be compared with the initial image (Fig. 11), showing progressive transformation into near-tree stature. The total change of the ground cover since the early-1980s is eclatant. Photo: 2019-06-07.

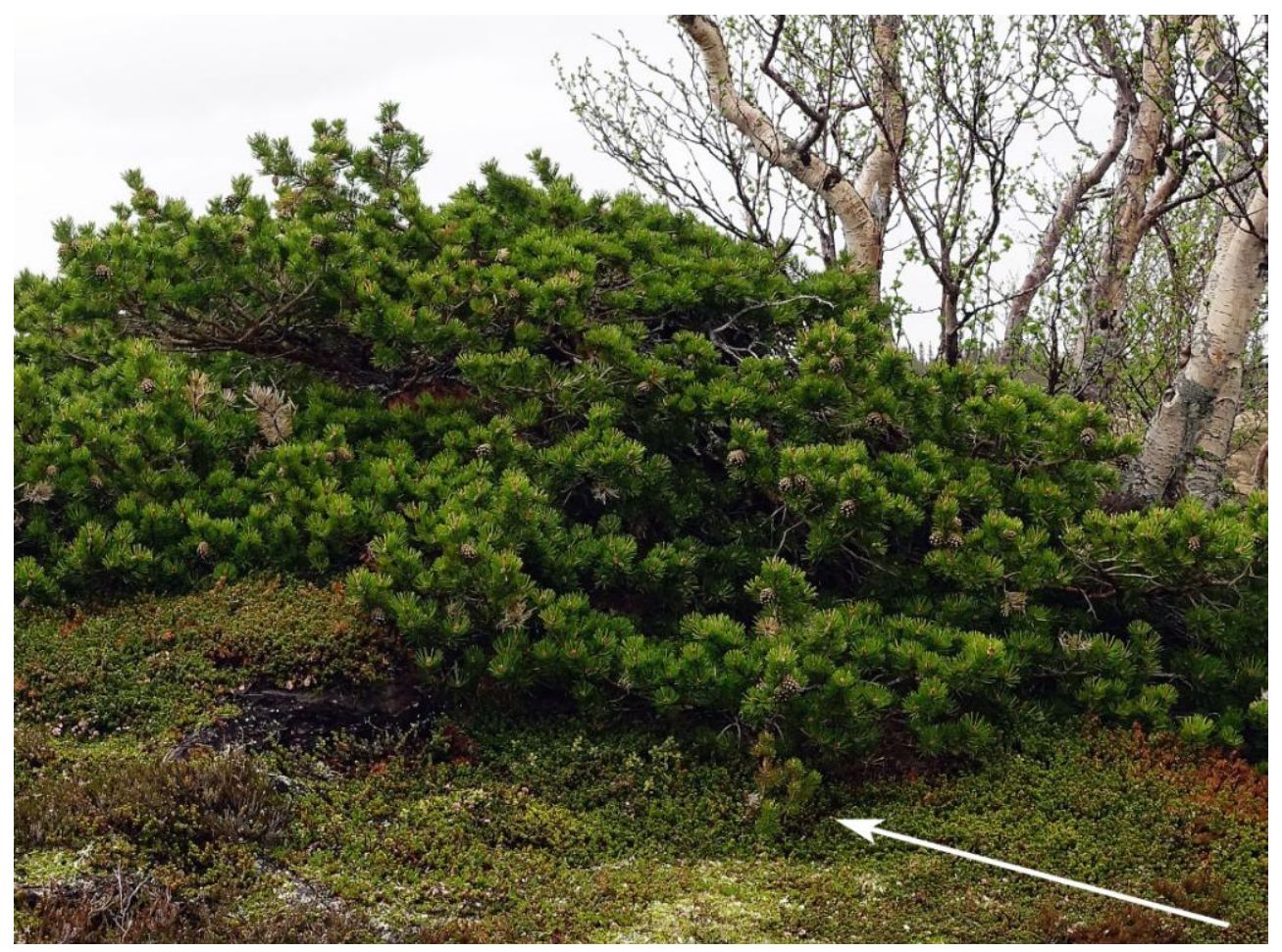

Fig. 19. In recent years, also this pine has produced some progeny (arrow) in its near circumference. Photo: 2017-06-10. 


\section{PINE 3}

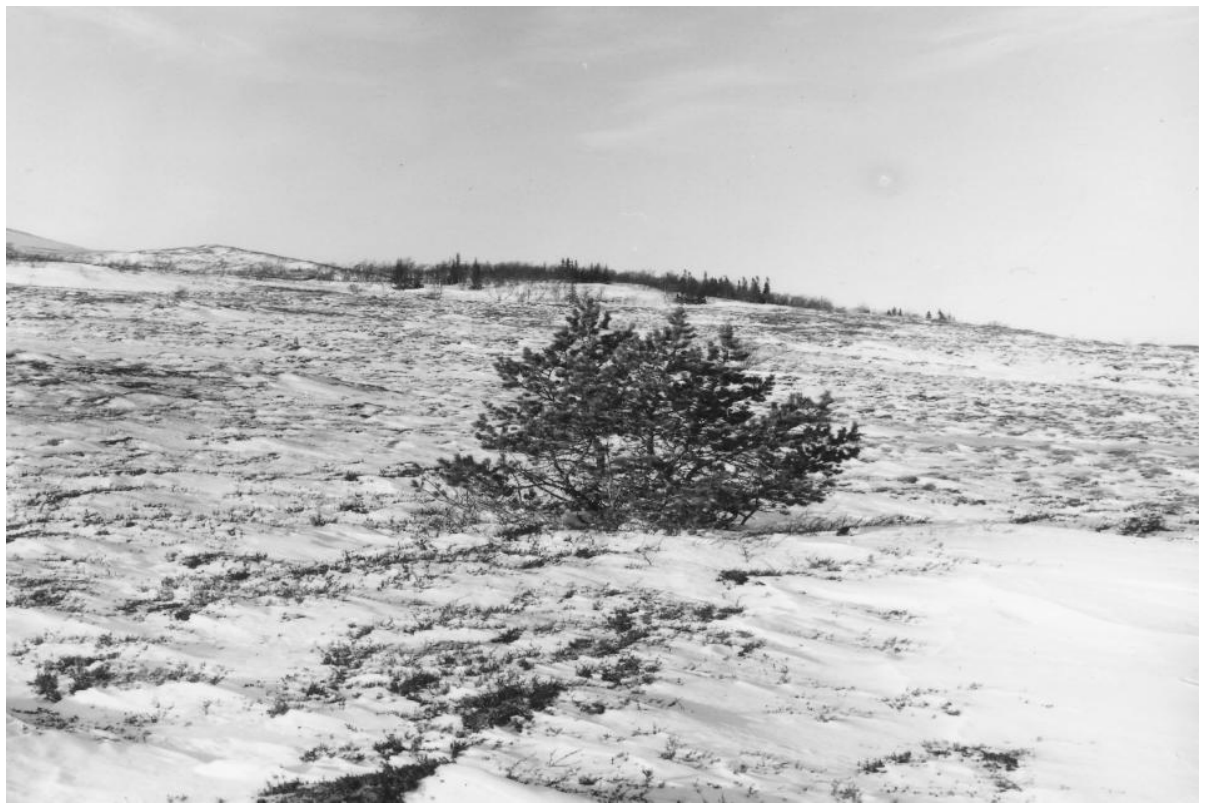

Fig. 20. The pine is multi-stemmed with a maximum of $2.1 \mathrm{~m}$. The site is a wind-exposed and snow-poor mire landscape. No offspring is recorded in the near circumference. The age is at least 350 years, although a rotten center precludes absolute dating. Photo: 1978-03-22.

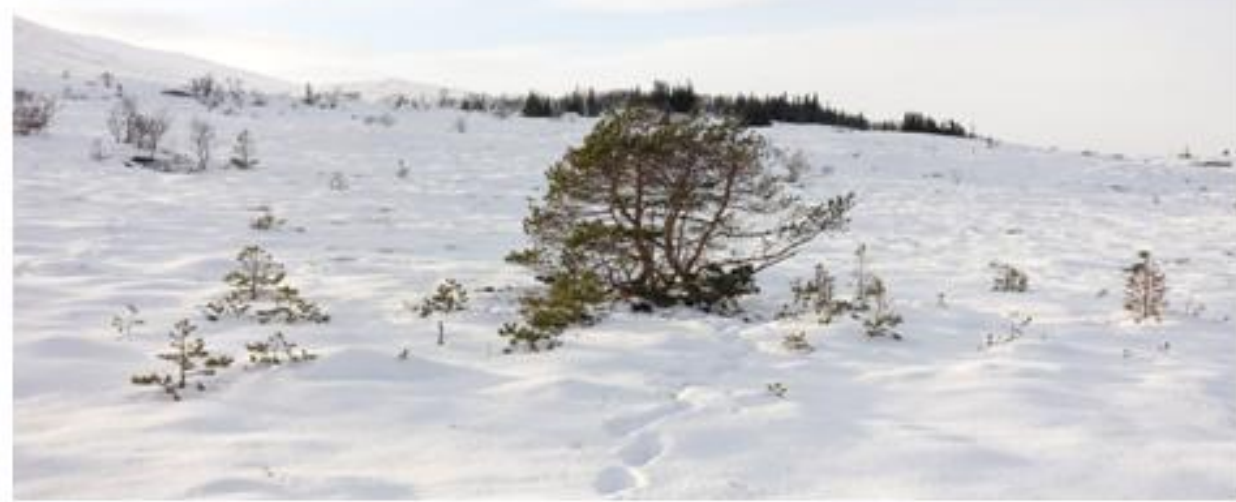

Fig. 21. Up to the present day, the height has increased to $3.5 \mathrm{~m}$ and a strong cohort of saplings has emerged during the past 10 years or so. Photo: 2019-11-07.

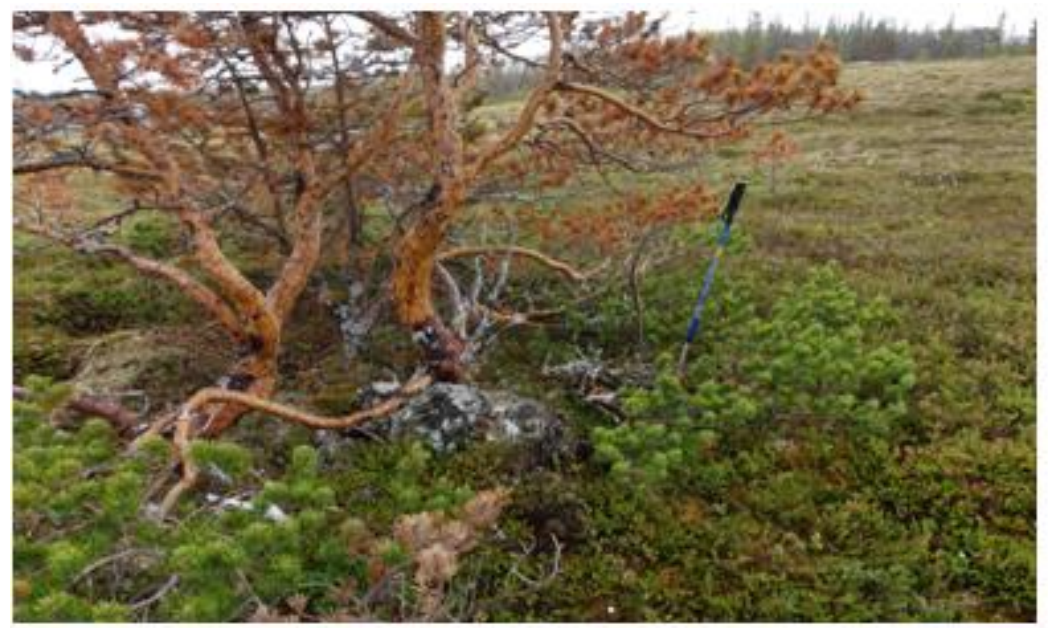

Fig. 22. Detailed view of the basal parts of the stem oldest stem, and a centrifugally spreading edging of layering stems with adventitious rots at a distance of 1-1.5 m. Compared to most of the stems, the oldest part of this clonal pine specimen is disproportionally thick. 


\section{DisCUSSION AND CONCLUSION}

Like most other important tree species forming elevational treelines in the Scandes, Pinus sylvestris may perform with long-lived layering clonal specimens around its elevational treeline. Due to the shade-intolerance of Pinus, individuals of this category are quite infrequent, as the treeline infiltrates the lower reaches of the still mainly dense and competitive subalpine birch forest belt. Hereabouts, pines rarely become established, and if so, they often fail to attain reproductive maturity. At these elevations, pine may establish primarily in wind-exposed glades, which imposes the striking windtrimmed physiognomy, displayed in this study. Obviously, there is an inverse relationship between birch and pine histories in the treeline ecotone (Kullman \& Öberg 2009; Kullman 2013).

Accordingly, it appears that in the case of continued climate warming and associated drought-induced birch stand-level dieback, pine individuals of the concerned kind may eventually turn into reproductive tree-size and make a contribution to the ongoing "pinification", elevational rise and compositional shift of the treeline ecotone (cf. Kullman 2014b, 2020, in press; Bognounou et al. 2018). Thereby they act as seed sources, dispersal nodes and advance bridgeheads, enabling extensive expansion into an eventually regressing birch forest. Projections of this trend into the future may possibly lead to a zonation pattern analogous to the situation prevailing during the Medieval Climate Optimum during the 10th to 14th centuries A.D. (Lamb 1982; Ljungqvist 2017), or even to the alltime-high early Holocene thermal peak, more than 7000 before the present (Kullman 2013, 2015b).

Apparently, the concerned growth forms of Pinus sylvestris represent environmentally "dwarfed" specimens. According to the terminology discussed by Holtmeier (1981), this category of individuals should be termed "cripple trees". In agreement with observed tendencies towards climatically changing growth forms and the more general use in the literature, we prefer the term "krummholz".

\section{REFERENCES}

[1] Aas, B. 1969. Climatically raised birch lines in southeastern Norway 1918-1968. Norsk Geografisk Tidsskrift 23, 119-130.

[2] Alatalo, J.M. \& Ferrarini, A. 2017. Braking effect of climate and topography on global change and topography on global change-induced upslope forest expansion. International Journal of Biometeorology 61(3), 541-548.

[3] Bekker, M.F. 2005. Positive feedback between tree establishment and patterns of subalpine forest advancement, Glacier National Park, Montana, U.S.A. Arctic, Antarctic, and Alpine Research 37, 97-107.

[4] Bernes, C. 2007. En ännu varmare värld. Växthuseffekten och klimatets förändringar. Naturvårdsverket, Stockholm.

[5] Behringer, W. 2010. A cultural history of climate. Polity Press, London.

[6] Bognounou, F., Hulme, P.E., Oksanen, L., Suominen, O. \& Olofsson J. 2018. Role of climate and herbivory on native and alien conifer seedling recruitment at and above the Fennoscandian tree line. Journal of Vegetation Science 29(4), 573-584..

[7] Elliott, G.P. \& Kipfmueller, K.I. 2010. Multi-scale influences of slope aspect and spatial pattern on ecotonal dynamics of upper treeline in the Southern Rocky Mountains, U.S.A. Arctic, Antarctic, and Alpine Research 42, 42-56.

[8] Franke, A.K., Feilhauer, H., Bräuning, A., Rautio, P. \& Braun, M. 2019. Remotely sensed estimation of vegetation shift in the polar and alpine treeline ecotone in Finnish Lapland during the last three decades. Forest Ecology and Management 454117668.

[9] Grove, J.M. 2004. Little Ice Ages. Ancient and modern, Routledge, London

[10] Hagedorn, F., Shiyatov, S.G., Mazepa, V.S. and 10 others 2014. Treeline advances along the Urals mountain range driven by improved winter conditions. Global Cahnge Biology 20, 3530-3543.

[11] Holtmeier, F.-K. 1981. What does the term "Krummholz" really mean? Observations with special reference to the Alps and the Colorado Front Range. Mountain Research and Development 1 (3-4), 253260.

[12] Holtmeier, F.-K. 2009. Mountain timberlines - ecology, patchiness, and dynamics. Springer, Dordrecht.

[13] Holtmeier, F.-K. \& Broll, G. 2010. Wind as an ecological agent at treelines in North America, TheAlps, and The European subarctic. Physical Geography 31, 203-233.

[14] Holtmeier, F.-K. \& Broll 2012. Landform influences on treeline patchiness and dynamics in a changing climate. Physical Geography 33(5), 403-437.

[15] Holtmeier, F.-K. \& Broll, G. 2017a. Treelines -approaches at different scales. Sustainability 9, 808. 
[16] Holtmeier, F.-K. \& Broll, G. 2017b. Feedback effects of clonal groups and tree clusters on site condition at the treeline: implications for treeline dynamics. Climate Research, doi: 10.3354/cr1431.

[17] Holtmeier, F.-K. \& Broll, G. 2017c. Layering in the Rocky Mountain treeline ecotone: clonal conifer groups' distribution, structure, and functional role. Trees 31, 953-965.

[18] Kallio, P., Laine, U. \& Mäkinen, Y. 1971. Vascular flora of Inari Lapland. 2. Pinaceae and Cupressacceae. Reports from the Kevo Subarctic Research Station 8, 73-100.

[19] Kaplan, J. O. \& New, M. 2006. Arctic climate change with $2{ }^{\circ} \mathrm{C}$ warming: Timing, climate patterns and vegetation change. Climate Change 79, 213-224.

[20] Kilander, S. 1955. Kärlväxternas övre gränser på fjäll i sydvästra Jämtland. Acta Phytogeographica Suecica 35, 1-198.

[21] Kullman, L. 1979. Change and stability in the altitude of the birch tree-limit in the southern Swedish Scandes. Acta Phytogeographica Suecica 65, 1-121.

[22] Kullman, L. 1986. Recent tree-limit history of Picea abies in the southern Swedish Scandes. Canadian Journal of Forest Research 16, 761-771.

[23] Kullman, L. 1998. Tree-limits and montane forests in the Swedish Scandes: sensitive biomonitors of climate change and variability. Ambio 27, 312-321.

[24] Kullman, L. 2011. Krummholz-tall på Täljstensvalen-gamla träd ger nya perspektiv. Lustgården 2011, 75 83.

[25] Kullman, L. 2013. Ecological tree line history and palaeoclimate - review of fossil evidence from the Swedish Scandes. Boreas 42, 555-567.

[26] Kullman, L. 2014a. Treeline (Pinus sylvestris) landscape evolution in the Swedish Scandes- a 40-year demographic effort viewed in a broader temporal context. Norwegian Journal of Geography 68(3), 155167.

[27] Kullman, L. 2014b. Trädgränsens förändring 1974 till 2013. Fotoserie från fjället Östra Barfredhågna i norra Dalarna. Länsstyrelsen i Dalarnas Län Rapport 2014(09), 1-67.

[28] Kullman, L. 2015a. Norway spruce (Picea abies (L.) Karst.) treeline ecotone performance since the mid1970 s in the Swedish Scandes - evidence of stability and minor change from repeat surveys and photography. Geo-Öko 36, 25-53.

[29] Kullman, L. 2015b. Higher-than-present Medieval pine (Pinus sylvestris) treeline along the Swedish Scandes. Landscape Online 42, 1-14.

[30] Kullman, L. 2016. Pine (Pinus sylvestris L.) penetration towards the head of the Handölan Valley: recent reversal of long-term retrogressional trend - contrasting responses to climate change of tree- and forest line. International Journal of Environmental \& Agriculture Research 2(5), 163-172.

[31] Kullman, L. 2017. Pine (Pinus sylvestris) treeline performance in the southern Swedish Scandes since the early 20th century. Acta Phytogeographica Suecica, 90, 1-46.

[32] Kullman, L. 2018. A recent and distinct pine (Pinus sylvetris L.) reproduction upsurge at the treeline in the Swedish Scandes. International Journal of Research in Geography 4(4), 39-52.

[33] Kullman, L. 2020. Early signs of a fundamental subalpine ecosystem shift in the Swedish Scandes-the case of the pine (Pinus sylvestris L.) treeline ecotone. Geo-Öko 40 (3-4), 122-175.

[34] Kullman, L. in press: Klibbal (Alnus glutinosa) - ännu en nygammal värmekrävande trädart i fjällbjörkskogen. [Alnus glutinosa - another thermophilic tree species in the subalpine mountain birch forest]. Svensk Botanisk Tidskrift Xxx, xxx-xxx.

[35] Kullman, L. \& Öberg, L. 2009. Post- Little Ice Age tree line rise and climate warming in the Swedish Scandes: a landscape ecological perspective. Journal of Ecology 97, 415-429.

[36] Kullman, L. \& Öberg, L. 2018. A one-hundred-year study of the upper limit of tree growth (Terminus Arboreus) in the Swedish Scandes-updated and illustrated change in an historical perspective. International Journal of Research in Geography 4(3), 10-35.

[37] Lamb, H.H. 1982. Climate, history and the modern world. Methuen, London.

[38] Leonelli, G., Pelfini, M., Morra di Cella, U. \& Caravaglia, V. 2011. Climate warming and the recent treeline shift in the European Alps: the role of geomorphological factors in high-altitude sites. Ambio 40, 264-273.

[39] Ljungqvist, F.C. 2017. Klimatet och människan under 12000 år. Dialogos Förlag, Stockholm.

[40] Moen, J., Aune, K., Edenius, L. \& Angerbjörn, A. 2004. Potential effects of climate change on treeline position in the Swedish mountains. Ecology \& Society 16, 1-10.

[41] Öberg, L. \& Kullman, L. 2011. Ancient subalpine clonal spruces (Picea abies) - sources of postglacial vegetation history in the Swedish Scandes. Arctic 64, 183-196. 
[42] Öberg, L. \& Kullman, L. 2012. Contrasting short-term performance of mountain birch (Betula pubescens ssp. czerepanovii) treeline along a latitudinal continentality - maritimity gradient in the southern Swedish Scandes. Fennia 190, 19-40.

[43] Nordhagen, R. 1928. Die Vegetation und Flora des Sylenegebietes. Die Vegetation. - Skr. utg. av Det Norske Vidensk.- Akad. i Oslo 1. Mat.-naturv. kl. 1927, N: o 1, 1-612.

[44] Payette, S., Filion, L., Delwaide, A. \& Bégin, C. 1989, Reconstruction of tree-line vegetation response to long-term climate change. Nature 341, 429-432.

[45] Payette, S. \& Lavoie, C. 1994. The arctic tree line as a record of past and recent climatic changes. Environ. Rev 2, 78-90.

[46] Smithson, P., Addison, K. \& Atkinson, K. 2002. Fundamentals of the physical environment. Routledge, London.

[47] Vesterlund, O. 1900. En liten tallstudie på Rotivare. Tidskrift för Skogshushållning 28(4), 216-218.

Citation: Leif Kullman*, Lisa Öberg. "The Recent History of Subalpine Krummholz Pines (Pinus Sylvestris) in the Swedish Scandes" International Journal of Research in Geography. vol 6, no. 1, 2020, pp. 16-28 doi: http://dx.doi. org/10.20431/2454-8685.0601003.

Copyright: (C) 2020 Authors. This is an open-access article distributed under the terms of the Creative Commons Attribution License, which permits unrestricted use, distribution, and reproduction in any medium, provided the original author and source are credited. 